\title{
Fertilization strategies for winter flounder: effects of spermatozoa density and the duration of gamete receptivity
}

\author{
Ian A. E. Butts ${ }^{1, *}$, Paymon Roustaian ${ }^{2}$, Matthew K. Litvak ${ }^{3}$ \\ ${ }^{1}$ Department of Biological Sciences, University of Windsor, Windsor, Ontario N9B 3P4, Canada \\ ${ }^{2}$ Department of Biology and Centre for Coastal Studies and Aquaculture, University of New Brunswick, Saint John, \\ New Brunswick E2L 4L5, Canada \\ ${ }^{3}$ Department of Biology, Mount Allison University, Sackville, New Brunswick E4L 1G7, Canada
}

\begin{abstract}
Winter flounder is one of the most commonly used models for studying fish biology in North America; however little is known about their reproductive ecology, especially during the spawning event. The objectives of this research were to determine the optimal number of spermatozoa required to fertilize eggs and to explore how long spermatozoa (30 to 240 s post-activation) and eggs (30 to $7680 \mathrm{~s}$ post-activation) are receptive to fertilization after exposure to seawater. We conducted experiments using gametes from wild-caught fish and measured fertilization success by examining eggs at 5 to $6 \mathrm{~d}$ post-fertilization. On average 34038 sperm cells per egg were required to fertilize $81.3 \%$ of the eggs. Duration after spermatozoa activation had an effect on the proportion of eggs fertilized $\left(F_{3,6.69}=338.38 ; \mathrm{p}<0.0001 ;\right.$ mixed-model ANOVA). At $30 \mathrm{~s}$ post-spermatozoa activation, $98 \%$ of the eggs were fertilized. After $60 \mathrm{~s}$, a significant decrease in fertilization success was detected. Duration after egg exposure to seawater had an effect on the proportion of eggs fertilized $\left(F_{8,16}=19.89 ; \mathrm{p}<0.0001\right.$; mixed-model ANOVA). For all trials (30 to $1920 \mathrm{~s}$ ), the percentage of eggs fertilized ranged from 61 to $90 \%$. A significant decrease to $11 \%$ occurred at $3840 \mathrm{~s}$ after egg exposure. This area of research has particular importance for our understanding of reproductive strategies, evolutionary challenges, reproductive potential and recruitment. In addition, examining sperm-egg interactions provides information important to management of living and frozen-thawed gene banks.
\end{abstract}

KEY WORDS: Marine fish $\cdot$ Reproduction $\cdot$ Sperm $\cdot$ Egg $\cdot$ Fisheries $\cdot$ Aquaculture $\cdot$ Segmented regression

Resale or republication not permitted without written consent of the publisher

\section{INTRODUCTION}

The number of reproductive adults, quantity of gametes released from spawning fish, spermatozoa and egg quality, as well as fertilization success (among others) determine the reproductive potential of fish stocks (Marshall et al. 1998, Trippel 1999, Marteinsdottir \& Begg 2002). Although not studied in great detail, an understanding of gamete interactions is clearly important and should be the starting point for examining reproductive ecology and recruitment potential of wild and cultivated stocks. In particular, we need to know: the number of spermatozoa required to fertilize each egg, the longevity of spermatozoa after exposure to water, and the length of time eggs are receptive to fertilization after release.

Eggs are often viewed as limited in supply. Spermatozoa because of their high numbers are not. However, this is not necessarily the case; spermatozoa for many species of fishes are limited (Rideout \& Burton 2000, Almeida et al. 2008). For example, spermatogonial proliferation in Atlantic cod of Norwe- 
gian coastal origin starts in August and continues for about 6 months and the number of pre-spawning spermatogonia present in the testes essentially determines the numbers produced each season (Almeida et al. 2008). In addition, since most fishes are external fertilizers and the medium in which the spermatozoa is released can be turbulent, i.e. oceans and rivers (Trippel 2003, Faria et al. 2006), there may not be an 'unlimited' number of spermatozoa available to fertilize eggs released by females in these environments.

Spermatozoa longevity and egg receptivity - the length of time an egg is receptive to be fertilized by a sperm cell-also impact the success of a fertilization event (Kjørsvik \& Lønning 1983, Trippel \& Morgan 1994, Butts et al. 2009). For instance, if female mate choice is important, then eggs may be receptive for a short period of time to reduce the chance of fertilization by non-desirable males. In contrast, if eggs are receptive for longer periods of time then the probability of fertilization by multiple males should increase; this may be important in situations when the probability of spermatozoa to egg encounters are low (Trippel 2003). If spermatozoa are viable for longer periods of time, then the potential of contacting and fertilizing an egg increases (Butts et al. 2009). However, if there is limited time available to fertilize an egg, then selection should favor faster-swimming spermatozoa. This will most likely be at the expense of longevity because there are limited amounts of energy reserves available for spermatozoa motility (Perchec et al. 1995, Burness et al. 2005, Butts et al. 2010). Ultimately, these gamete strategies provide an evolutionary challenge for fertilization for both males and females, as evidenced by counter-strategies employed. Therefore, an inspection of spermatozoa longevity and egg receptivity provides valuable information on reproductive behavior; i.e. whether a species employs a promiscuous or a nonpromiscuous mating system.

Even though winter flounder Pseudopleuronectes americanus is one of the most studied marine fishes in North America (626 title citations reported in Web of Science on 13 Jan 2012) little is known about its reproductive ecology. Winter flounder is a benthic right-eyed flatfish (Family Pleuronectidae) distributed throughout the North Atlantic Ocean from Labrador, Canada to Georgia, USA (Bigelow \& Schroeder 1953). Winter flounder are primarily found in shallow coastal waters and estuaries although several offshore populations exist, including the Sable Island Bank population, the Western and Browns Bank population on the Scotian Shelf, and the Georges Bank population (McClelland et al. 2005). Spawning occurs from late winter in southern areas to early spring in northern areas (Scott \& Scott 1988). Winter flounder are $r$-selected (produce many small eggs), single batch spawners and females produce from 192240 to 3.33 million eggs per season (Scott \& Scott 1988, Buckley et al. 1991). Winter flounder males, like many other fish species, undergo spermatogenesis in the fall (Moulton \& Burton 1999) and the spermatozoa produced during gonad maturation is limited to the number of spermatogonia present in the testes of each male. Artificial fertilization has long been used to generate embryos and larvae for winter flounder. High fertilization and hatch success rates have been reported with the use of both fresh and cryopreserved spermatozoa (Rideout et al. 2003, Butts \& Litvak 2007a,b). Thus winter flounder are an ideal model species to examine sperm and egg interactions in the laboratory.

Here, we conducted a laboratory experiment to determine the optimal number of spermatozoa required to fertilize winter flounder eggs in a controlled setting. We also explore how long spermatozoa are viable and eggs are receptive after exposure to seawater. The hope is that this work will shed light on the reproductive ecology of this species.

\section{MATERIALS AND METHODS}

\section{Broodstock husbandry and gamete collection}

Adult winter flounder were obtained in March 2006 from the Western Passage of Passamaquoddy Bay, New Brunswick, Canada, using bottom trawl. Mean ( \pm SD) total length of the broodstock was $26.7 \pm$ $4.8 \mathrm{~cm}$. After capture and transport, broodstock were held at the University of New Brunswick, Saint John, in a 27001 closed recirculation system. Temperature and salinity ranged from 2 to $3^{\circ} \mathrm{C}$, and 27 to $30 \mathrm{ppt}$, respectively. Dissolved oxygen remained above 10.1 $\mathrm{mg} \mathrm{l}^{-1}$. Broodstock were maintained under ambient photoperiod regime and were not fed while in captivity (e.g. Litvak 1999, Butts \& Litvak 2007 a,b).

Sperm cells were collected from 33 randomly selected adult male winter flounder. Sperm samples were obtained by applying light pressure on the abdomen and collecting semen in $3 \mathrm{ml}$ syringes. To avoid seawater and urine contamination, the initial male ejaculate was discarded and the external urogenital pore was wiped dry with a paper towel. After stripping, syringes were held in a glass beaker placed in a cooler filled with crushed ice until used for experimentation. Spermatozoa motility was evaluated by placing $1 \mu \mathrm{l}$ of spermatozoa on a microscope 
slide, activated with $40 \mu \mathrm{l}$ of seawater, and covered with a coverslip. Motility was estimated at 10 s postactivation using an arbitrary scale of 6 scores ranging from 0 to 5 where $0=$ no motility, $1=1$ to $19 \%, 2=20$ to $39 \%, 3=40$ to $59 \%, 4=60$ to $79 \%, 5=80$ to $100 \%$ (Suquet et al. 1998). Three replicate activations were completed for each male. For all activations, males had motility scores of 5 .

Female broodstock were checked daily for signs of ovulation. Once the female's egg pore had swelled outside the body cavity, eggs were stripped by applying light pressure to the abdomen, and expelled eggs were collected into dry $100 \mathrm{ml}$ beakers. Egg quality was immediately assessed after collection; eggs from females that were not clear and spherical were not used for experimentation.

All instruments and seawater used for fertilization were kept at 7 to $8^{\circ} \mathrm{C}$. We conducted all fertilization trials and incubated the eggs inside a temperaturecontrolled room at 7 to $8^{\circ} \mathrm{C}$ prior to determination of fertilization success.

\section{Expt 1: Determination of spermatozoa to egg ratio}

Eggs from each of 5 females were crossed with the spermatozoa from 3 males. Different males $(n=3)$ were used for each female, resulting in a total of 15 parental half-sibling families. Seawater (28 ppt) contained $13 \mathrm{mg} \mathrm{l}^{-1}$ of penicillin $\mathrm{G}$, and $13 \mathrm{mg} \mathrm{l}^{-1}$ of streptomycin sulfate (Butts \& Litvak 2007a,b). After collection, eggs were placed into $100 \times 15 \mathrm{~mm}$ Petri dishes (450 eggs per Petri dish, which is equal to $\sim 0.1 \mathrm{ml}_{\text {; }}$ authors' unpubl. data), using a $1.0 \mathrm{ml}$ syringe. Based on the experimental design we did not have enough time to determine the actual spermatozoa density for each male prior to experimentation (determined at a later stage; see below). Therefore, we used the value from Harmin \& Crim (1993) of $1.64 \times 10^{10}$ spermatozoa ml ${ }^{-1}$ to initially set the 6 spermatozoa to egg ratios we tested. We attempted to develop a range of spermatozoa to egg ratios on a logarithmic scale from 100 to 10 million spermatozoa per egg. Three replicate crosses were completed for each spermatozoa to egg ratio. Spermatozoa were added directly to the eggs in each dish using a dry fertilization approach. The spermatozoa-egg solution was gently swirled to homogenize the mixture and then $40 \mathrm{ml}$ of seawater was added to activate the gametes. Using this fertilization technique will allow the eggs to stick to the bottom of the Petri dish in a mono-layer. Egg and spermatozoa contact time was set at approximately $5 \mathrm{~min}$. After this period, gametes were rinsed with $20 \mathrm{ml}$ of seawater, and then Petri dishes were refilled with $40 \mathrm{ml}$ and left to incubate until being examined for fertilization success. Fertilization success was examined on a mean $( \pm$ SEM) of $43.9 \pm 0.74$ eggs per Petri dish.

In order to determine the actual spermatozoa density per male we cryopreserved the fresh sperm from each male in liquid nitrogen (following Rideout et al. 2003) to be later analyzed. Frozen-thawed semen from each male was later counted under a compound microscope (Olympus BX-40) at 400x magnification using an improved Neubauer haemocytometer. Milt from each male was first diluted 500-fold in a sucrose-based diluent (125 mM Sucrose, $100 \mathrm{mM}$ $\mathrm{KHCO}_{3}, 6.5 \mathrm{mM}$ reduced glutathione $98 \%$; $\mathrm{pH}$ 8.1) that does not activate sperm (Rideout et al. 2003). Milt-diluent samples were mixed on a vortex mixer in order to obtain a homogenous mixture. Triplicate dilutions were made for each male sample. Three counts of 5 squares $\left(1 \mathrm{~mm}^{2}\right)$ were inspected for each dilution. The mean of the 3 counts for each dilution was calculated, and then the mean of these 2 values was used to determine the actual spermatozoa density $\mathrm{ml}^{-1}$ per male.

\section{Expt 2: Spermatozoa longevity}

Eggs from each of 3 females were crossed with the spermatozoa from 3 males producing 3 half-sibling families per female, and resulting in a total of 9 parental half-sibling families. Milt $(1 \mathrm{ml})$ was diluted in $219 \mathrm{ml}$ of seawater and mixed for $15 \mathrm{~s}$. The next $20 \mathrm{ml}$ of this solution was added to 450 eggs in a Petri dish $(100 \times 15 \mathrm{~mm})$ after $30,60,120$ and 240 s postsperm activation. After $\sim 5$ min of gamete contact, excess spermatozoa were rinsed with $20 \mathrm{ml}$ of seawater, and the Petri dishes were refilled with $40 \mathrm{ml}$ of seawater and left to incubate. Fertilization success was examined on a mean $( \pm$ SEM) of $18.5 \pm 0.9$ eggs per dish.

\section{Expt 3: Egg longevity}

Eggs from each of 3 females were crossed with the spermatozoa from 3 males producing 3 half-sibling families per female, resulting in a total of 9 parental half-sibling families. To perform experimental crosses, we first added 450 eggs to a dry petri dish $(100 \times$ $15 \mathrm{~mm}$ ). Next, $10 \mathrm{ml}$ of seawater was added to the eggs in each dish. The eggs remained in seawater for $30,60,120,240,480,960,1920,3840$ and $7680 \mathrm{~s}$ before semen was added for fertilization (according 
to Expt 2). After $\sim 5$ min gamete contact, excess spermatozoa were rinsed with $20 \mathrm{ml}$ of seawater, and sequentially refilled with $40 \mathrm{ml}$ of seawater and left to incubate. Fertilization success was examined on mean $( \pm$ SEM $)$ of $58.7 \pm 1.3$ eggs per Petri dish.

\section{Expts 1 to 3: Embryo incubation and fertilization success}

Every second day, $75 \%$ of the sterilized seawater in each Petri dish was replaced. At 5 to $6 \mathrm{~d}$ post fertilization, egg and/or embryos were randomly sampled from each parental treatment combination and observed under low light using a dissecting microscope (Wild Heerbrugg; at 40× magnification) in order to determine fertilization success. Fertilization success was calculated as the percent fertilized eggs. Embryos that had developed to the late epiboly or early somite stage were considered fertilized.

\section{Statistical analysis}

All data were analyzed using SAS statistical analysis software (v.9.1; SAS Institute 2003). Residuals were tested for normality (Shapiro-Wilks test; PROC UNIVARIATE; SAS Institute 2003) and homogeneity of variance (plot of residuals vs. predicted values; PROC GPLOT; SAS Institute 2003). Fertilization success was arcsin square-root transformed (Zar 1996). Alpha was set at 0.05 for main effects and interactions.

\section{Expt 1: Determination of spermatozoa to egg ratio}

Segmented linear regression analysis was used to analyze the data based on the adjusted spermatozoa cell densities per male, and a breakpoint (or threshold) was calculated (SAS PROC NLIN; SAS Institute 2003). Segmented linear regression is an iterative model that, if valid, will converge to solve for a breakpoint between 2 linear relationships: one slope and one asymptote. In our study this breakpoint reflects the number of spermatozoa after which adding more spermatozoa to the eggs will not significantly increase the percent fertilization (following Robbins et al. 2006). Breakpoints were generated for each male-female combination. The parameters for the segmented regression were defined as $R$, the breakpoint $x$-value, and $\mathrm{L}$, the asymptote on the $y$ axis at R (Robbins et al. 2006).

\section{Expts 2 and 3: Spermatozoa and egg longevity}

Fertilization success (Y) was analyzed using a mixed-model nested factorial ANOVA (PROC MIXED; SAS Institute 2003):

$\mathrm{Y}_{i k p n}=\mu+\mathrm{A}_{i}+\mathrm{B}(\mathrm{A})_{k(i)}+\mathrm{C}_{p}+\mathrm{AC}_{i p}+\mathrm{BC}(\mathrm{A})_{k p(i)}+\varepsilon_{\mathrm{n}(i k p)}$

where $\mu$ is the true mean; $A_{i}$ is the female effect (where $i=1-3$ ); $\mathrm{B}(\mathrm{A})_{k(i)}$ is the male effect (where $k=$ 1-4) nested within female; $C_{p}$ is the effect of gamete longevity (where $p=1-4$ for sperm longevity and 1-8 for egg longevity); $\mathrm{AC}_{i p}$ is the female $\times$ gamete contact interaction; $\mathrm{BC}(\mathrm{A})_{k p(i)}$ is the male $\times$ gamete contact nested within female interaction; and $\varepsilon_{n(i k p)}$ is the residual error. Female and male effects were considered random, while gamete longevity was considered fixed. Denominator degrees of freedom for all F-tests were approximated using the Satterthwaite procedure (Satterthwaite 1946). A posteriori analyses performed on fixed effects were constructed using Tukey's multiple comparisons procedure. Note that in SAS PROC MIXED models, F-ratios and p-values are only generated for fixed effects (Littell et al. 1996, SAS Institute 2003).

\section{RESULTS}

\section{Expt 1: Determination of spermatozoa to egg ratio}

Spermatozoa densities for the males ranged from $8.10 \times 10^{9}$ to $17.7 \times 10^{9}$ sperm cells $\mathrm{ml}^{-1}$ (Table 1 ). All segmented regressions models successfully converged except for Male 9. Models were significant for each of the males $\left(F_{2,27} \geq 26.1 ; p<0.0001\right)$. Mean and confidence limits for $\mathrm{L}$ and $\mathrm{R}$ were calculated for each male (Fig. 1; Table 2). On average 34038 sperm cells per egg were required to fertilize $81.3 \%$ of the eggs.

Table 1. Pseudopleuronectes americanus. Actual spermatozoa densities and the mean for the 15 winter flounder males used in Expt 1

\begin{tabular}{|lc|cc|}
\hline Male & $\begin{array}{c}\text { Spermatozoa } \\
\mathrm{ml}^{-1}\end{array}$ & Male & $\begin{array}{c}\text { Spermatozoa } \\
\mathrm{ml}^{-1}\end{array}$ \\
\hline 1 & $8.5 \times 10^{9}$ & 9 & $14.1 \times 10^{9}$ \\
2 & $12.4 \times 10^{9}$ & 10 & $11.4 \times 10^{9}$ \\
3 & $17.7 \times 10^{9}$ & 11 & $10.4 \times 10^{9}$ \\
4 & $9.6 \times 10^{9}$ & 12 & $9.5 \times 10^{9}$ \\
5 & $11.5 \times 10^{9}$ & 13 & $8.1 \times 10^{9}$ \\
6 & $10.1 \times 10^{9}$ & 14 & $10.1 \times 10^{9}$ \\
7 & $8.8 \times 10^{9}$ & 15 & $10.9 \times 10^{9}$ \\
8 & $14.6 \times 10^{9}$ & Mean & $11.2 \times 10^{9}$ \\
\hline
\end{tabular}



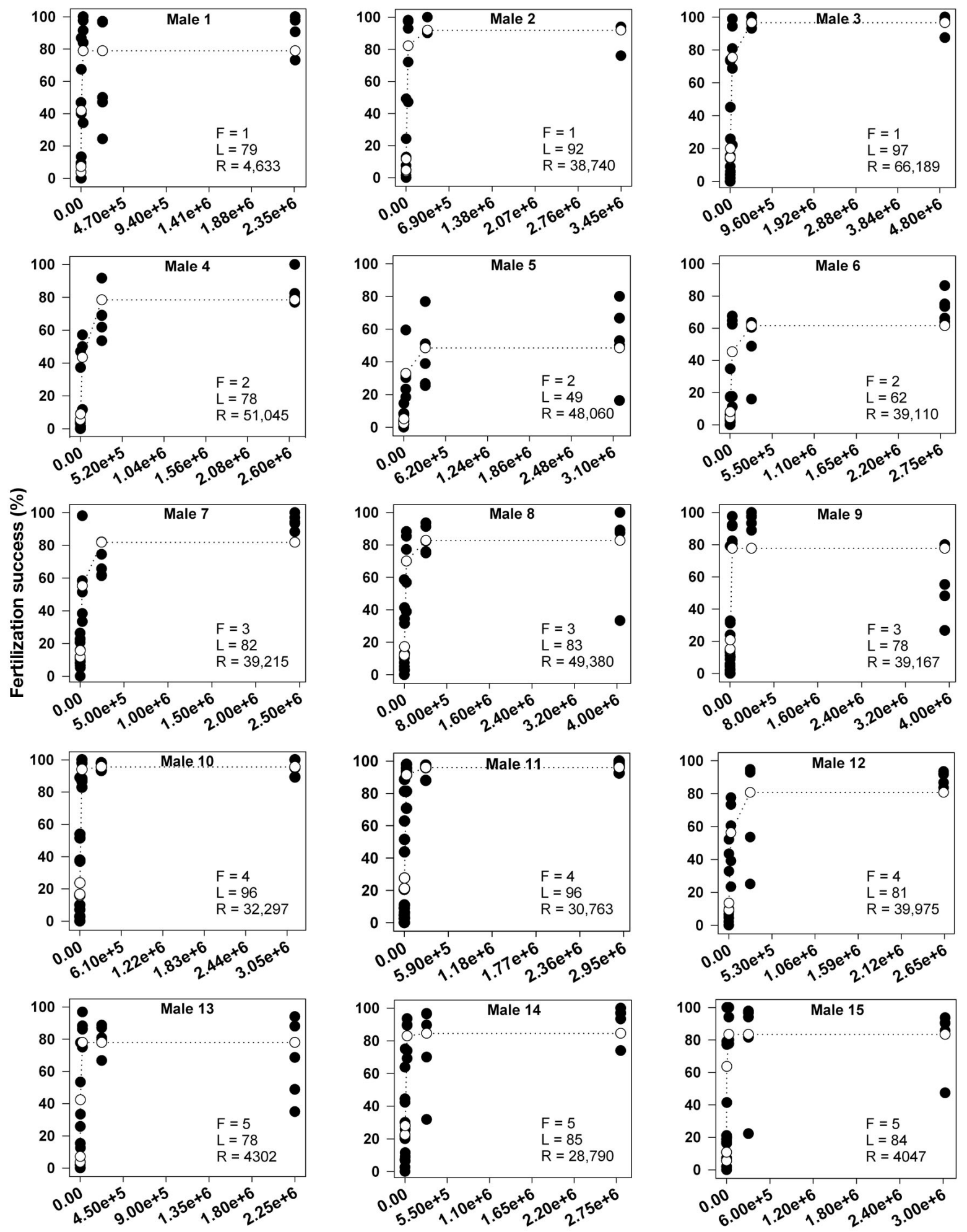

\section{Spermatozoa to egg ratio}

Fig. 1. Pseudopleuronectes americanus. In Expt 1, segmented linear regression analysis was used to analyze the winter flounder data and a breakpoint was calculated for each male-female combination. This breakpoint reflects the number of spermatozoa after which adding more spermatozoa to the eggs will not significantly increase the percent fertilization. $\mathrm{F}=$ female number, $\mathrm{R}=$ breakpoint $x$-value (spermatozoa to egg ratio), $\mathrm{L}=$ the asymptote on the $y$-axis at $\mathrm{R}$ (\% of eggs fertilized), open circles $=$ predicted values, closed circles $=$ observed values 
Table 2. Pseudopleuronectes americanus. In Expt 1, segmented linear regression analysis was used to analyze the data, based on the adjusted sperm cell densities per winter flounder male. A breakpoint was calculated for each male-female combination. Breakpoints reflect the number of spermatozoa after which adding more spermatozoa to the eggs did not significantly increase the percent fertilization. The parameters for the segmented regression were defined as R, the breakpoint $x$-value (number of sperm cells), and L (expressed as $\%$ fertilization), the asymptote on the $y$-axis at R (Robbins et al. 2006). Confidence limits (lower and upper) for $\mathrm{R}$ and $\mathrm{L}$ were calculated for each malefemale combination and mean values presented

\begin{tabular}{|lcrrrrrr|}
\hline \multirow{2}{*}{ Female } & Male & $\mathrm{L}$ & $\mathrm{R}$ & $\mathrm{L}_{\text {lower }}$ & $\mathrm{L}_{\text {upper }}$ & $\mathrm{R}_{\text {lower }}$ & $\mathrm{R}_{\text {upper }}$ \\
\hline 1 & 1 & 78.9 & 4633.0 & 65.7 & 92.1 & 1520.1 & 7745.9 \\
1 & 2 & 91.9 & 38740.0 & 81.6 & 102.2 & 31159.4 & 46320.9 \\
1 & 3 & 96.6 & 66188.7 & 82.9 & 110.3 & 42260.3 & 90117.2 \\
2 & 4 & 78.4 & 51045.0 & 68.5 & 88.4 & 28062.2 & 74028.4 \\
2 & 5 & 48.5 & 48060.4 & 39.2 & 57.7 & 25002.3 & 71118.5 \\
2 & 6 & 61.5 & 39109.7 & 50.8 & 72.3 & 22729.1 & 55490.3 \\
3 & 7 & 81.8 & 39214.6 & 72.4 & 91.2 & 25852.6 & 52576.6 \\
3 & 8 & 82.8 & 49380.4 & 70.7 & 94.9 & 32552.7 & 66208.2 \\
3 & 9 & 77.7 & 39166.7 & 65.7 & 89.6 & -115340.0 & 193673.0 \\
4 & 10 & 95.6 & 32297.0 & 83.9 & 107.2 & 24035.4 & 40559.8 \\
4 & 11 & 96.0 & 30762.7 & 82.1 & 110.0 & 20491.9 & 41033.5 \\
4 & 12 & 80.7 & 39974.6 & 68.0 & 93.4 & 22918.2 & 57031.0 \\
5 & 13 & 78.0 & 4302.0 & 69.4 & 86.5 & 2467.8 & 6136.8 \\
5 & 14 & 84.6 & 28789.6 & 70.9 & 98.3 & 17745.6 & 39833.7 \\
5 & 15 & 83.5 & 4047.0 & 72.7 & 94.2 & 2612.8 & 5480.6 \\
Mean & 81.3 & 34038.9 & 69.9 & 92.8 & 21386.5 & 46691.5 \\
a The segmented regression model for Male 9 did not successfully con- \\
verge, therefore Male 9 values were not used to calculate the mean for \\
each parameter estimate
\end{tabular}

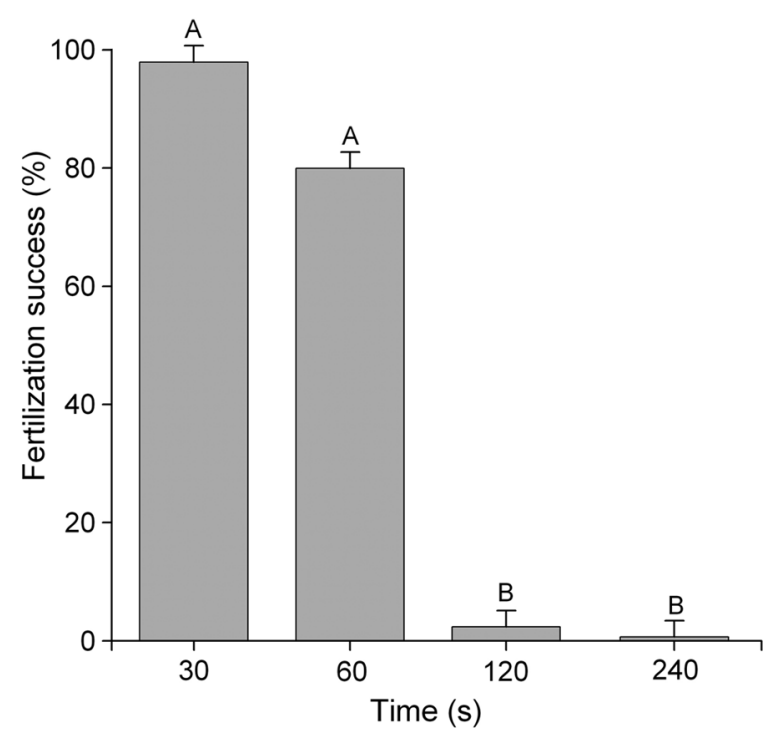

Fig. 2. Pseudopleuronectes americanus. Length of time spermatozoa (30-240 s post-activation) are capable of fertilizing eggs after exposure to seawater. Error bars represent least square means standard error (PROC MIXED; SAS Institute 2003). Bars with different letters are significantly different $(\mathrm{p}<0.05$, least square means, ANOVA)

\section{Expt 2: Spermatozoa longevity}

Duration after spermatozoa activation had a significant effect on proportion of eggs fertilized $\left(F_{3,6.69}=338.38\right.$; $\mathrm{p}<0.0001$; Fig. 2). At $30 \mathrm{~s}$ postspermatozoa activation, $98 \%$ of the eggs were fertilized on average. At 120 s post-spermatozoa activation, we observed a significant decrease in fertilization success.

\section{Expt 3: Egg longevity}

Duration after egg exposure to seawater had a significant effect on proportion of eggs fertilized $\left(F_{8,16}=\right.$ 19.89; $\mathrm{p}<0.0001$; Fig. 3). Between 30 and $1920 \mathrm{~s}$ after exposure to seawater, the percentage of eggs fertilized ranged from 61 to $90 \%$. A significant decrease to $11 \%$ occurred at $3840 \mathrm{~s}$ after egg exposure to seawater (Fig. 3).

\section{DISCUSSION}

Spermatozoa to egg ratios can inform us about the reproductive ecology of fishes. To date including the present study, we currently know spermatozoa to egg ratios for only 15 of the $\sim 28000$ species of fishes (Table 3). We found, as would be expected, that increasing spermatozoa cell density increased fertilization success. However, the position of the breakpoints for the segmented regressions were highly variable between males, suggesting the fertilization potential is specific to the individual male; this is a result of a male only contributing sperm to reproduction. When considering our fish's spermatozoa traits, all males had high $(\geq 80 \%)$ motility. Butts \& Litvak (2007a) examined the contribution of parental effects on reproductive success and found that the paternity significantly influenced fertilization in winter flounder. Therefore, further work is required to establish a linkage between spermatozoa traits (i.e. adenosine-5'-triphosphate concentration, morphology, seminal plasma biochemistry; Lahnsteiner et al. 1998, Asturiano et al. 2005, Alavi et al. 2011, Butts et al. 2011) and fertilization ability for this species. Such information would be an important early indicator for evaluation of a male's reproductive potential (Trippel 2003). 


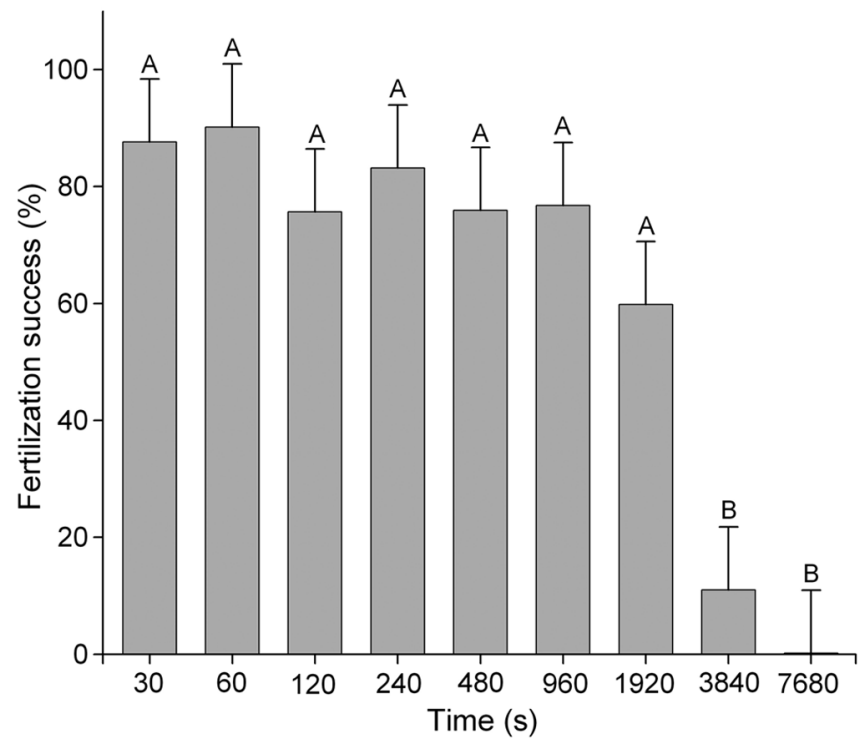

Fig. 3. Pseudopleuronectes americanus. Length of time eggs (30-7680 s post-activation) are receptive to fertilization after exposure to seawater. Error bars represent least square means standard error (PROC MIXED; SAS Institute 2003). Bars with different letters are significantly different $(\mathrm{p}<$ 0.05 , least square means, ANOVA)

The number of spermatozoa needed to fertilize one ovum in fish is relatively high and species dependent, and even within the same species different optimal spermatozoa to egg ratios have been reported by different studies (Table 3). For example, rainbow trout Oncorhynchus mykiss was found to have an optimal spermatozoa to egg ratio of 75000 (Erdahl \& Graham 1987) and 300000 (Billard 1975). This intraspecies variability may be an artifact of different fertilization environments (i.e. amount of water used to activate the gametes; Table 3 ) or may be attributed to gamete quality at the time of stripping. Nevertheless, such high numbers of spermatozoa are necessary for fertilization since each egg has a unique point(s) of penetration, the micropyle, which the spermatozoa have little chance of reaching when their concentration is low or when their motility, velocity, or longevity (among others) is reduced. In the present study, the lower and upper confidence limits of 21386 to 46691 winter flounder spermatozoa per egg are required to fertilize on average $81.3 \%$ of the eggs, which is in the middle of the range of spermatozoa to egg ratios currently found in the literature (Table 3).

Spermatozoa to egg ratio results from the present study are useful for laboratory work on winter flounder as well as in modelling what may be occurring in nature. This approach can provide insight into spawning behavior and ecology in winter flounder. For example, using our data, and that from the literature-(1) winter flounder females are single batch spawners producing between 192240 and 3.33 million eggs per season (Scott \& Scott 1988, Buckley et al. 1991); and (2) males, which recruit their spermatogonia in the fall, have a finite supply of spermatozoa we can generate a simple model to inspect the spawning ecology of winter flounder. Since males produce

Table 3. The optimal number of spermatozoa needed to fertilize an ovum in fish. Spermatozoa:egg ratio reflects the number of spermatozoa after which adding more spermatozoa to the eggs will not significantly increase fertilization success; AM = activation medium; ${ }^{\mathrm{DF}}=$ dry fertilization; ${ }^{\mathrm{WF}}=$ wet fertilization; $\mathrm{nd}$ : no data

\begin{tabular}{|lccl|}
\hline Fish species & Spermatozoa:egg ratio & Volume of AM & Reference \\
\hline African catfish Clarias gariepinus & 15000 & $10 \mathrm{ml}$ & Rurangwa et al. (1998) \\
Asian catfish Clarias macrocephalus & 4000 & $0.5 \mathrm{ml} \mathrm{g} \mathrm{egg}^{-1}$ & Tambasen-Cheong et al. (1995) \\
Atlantic cod Gadus morhua & 100000 & $40 \mathrm{ml}$ & Butts et al. (2009) \\
Brown trout Salmo trutta & 43000 & $\mathrm{nd}$ & Erdahl \& Graham (1987) \\
Common carp Cyprinus carpio & 236720 & $5 \mathrm{ml}$ & Linhart et al. (2003) \\
European catfish Silurus glanis & $800-80000$ & $6 \mathrm{ml}$ & Linhart et al. (2004) \\
Herring Clupea harengus & 9600000 & $\mathrm{nd}$ & Rosenthal et al. (1988) \\
Northern pike Esox Lucius & 26000 & $\mathrm{nd}$ & Erdahl \& Graham (1987) \\
Pacu Piaractus mesopotamicus & 7000 & $15-60 \mathrm{ml}$ & Sanches et al. (2011) \\
Rainbow trout Oncorhynchus mykiss & 300000 & $\mathrm{nd}$ & Billard (1975) \\
& 75000 & $\mathrm{nd}$ & Erdahl \& Graham (1987) \\
Sea lamprey Petromyzon marinus & 50000 & $10 \mathrm{ml}$ & Ciereszko et al. (2000) \\
Turbot Scophthalmus maximus & 6000 & $1-19 \mathrm{ml}$ & Suquet et al. (1995) \\
& $>9000^{\mathrm{DF}} / 3000-4000^{\mathrm{WF}}$ & $100 \mathrm{ml}$ & Chereguini et al. (1999) \\
Walleye Sander vitreus & 25000 & $\mathrm{nd}$ & Rinchard et al. (2005) \\
Winter flounder Pseudopleuronectes americanus & 500000 & $400 \mathrm{ml}$ & Casselman et al. (2006) \\
Wolffish Anarhichas lupus & 200000 & $40 \mathrm{ml}$ & This study \\
& & $\mathrm{nd}$ & Moksness \& Pavlov (1996) \\
\hline
\end{tabular}


on average $2.2 \mathrm{ml}$ of milt per season, at an average spermatozoa density of $1.64 \times 10^{10}$ per $\mathrm{ml}$, the total number of spermatozoa produced per season is $3.6 \times$ $10^{10}$ (Harmin \& Crim 1993, this study). Therefore, the ratio of spermatozoa to eggs for a less fecund female (192 240 eggs) is $187682: 1$; for a highly fecund female (3.33 million eggs) it is $10835: 1$. Clearly, if an average male encountered a lower fecund female, he would be able to fertilize all of her eggs as the number of spermatozoa per egg ratio is less than the optimal observed for our fish. However, if an average male were to encounter a large and highly fecund female, he would not be able to fertilize all her eggs, as the spermatozoa per egg ratio is below our confidence limits. One caveat here is that fertilization conditions in the laboratory are perfect; i.e. no currents advecting away the spermatozoa as well as spermatozoa and eggs placed in close proximity for a long duration. Therefore, we would expect that spermatozoa contact time and density in the wild should be much less, suggesting that it might take more than 1 male to fertilize the eggs of 1 gravid female. Overall, these results suggest that winter flounder may be promiscuous, and a skewed sex ratio towards males may be advantageous in the wild to maintain recruitment.

Most research on spermatozoa longevity has focused on freshwater species, for which spermatozoa longevity persists for 1 to 2 min while marine species can remain motile up to $2 \mathrm{~h}$ (reviewed by Suquet et al. 1994). Winter flounder males do not seem to have spermatozoa that remain viable as long as other marine species. However, we found that winter flounder eggs can be fertilized for up to $32 \mathrm{~min}$ after the female has released eggs into seawater. These 2 points, in addition to the spermatozoa to egg ratio results, also suggest promiscuous mating strategies for this species. Increased egg receptivity will allow a female a greater chance to have her eggs fertilized by more than 1 male. Additionally, if males ration their spermatozoa and fertilize more than 1 female's eggs, then this too suggests multiple partners for reproduction. Stoner et al. (1999) examined mating behavior of winter flounder in tanks and found that spawning most often involved multiple males. Our results, in combination with that of Stoner et al. (1999), suggest multiple mates for females.

Studies on optimal spermatozoa to egg ratios and gamete interactions are also extremely important for routine production of winter flounder for aquaculture and conservation efforts. Ultimately, both these efforts can be enhanced with the use of cryogenic technology, as the cryopreservation process has been shown to have no effect on a sperm cell's ability to fertilize an egg for this species (Rideout et al. 2003). Once frozen, sperm cells from different stocks and lineages become a 'priceless commodity'; i.e. frozen-thawed cells can be used to perform what is called 'genetic rescue' if it is needed. Therefore, using our results we can now determine how many eggs each cryogenic spermatozoa straw can fertilize for routine production. By taking the average number of spermatozoa from the 15 males used in Expt 1, which equals $1.12 \times 10^{10}$ sperm cells $\mathrm{ml}^{-1}$, each $0.25 \mathrm{ml}$ cryogenic sperm straw (containing 1 part sperm to 3 parts extender) contains $0.0625 \mathrm{ml}$ or $7.0 \times 10^{8}$ sperm cells. Using the mean ratio of 34038 spermatozoa to egg, each cryopreserved straw should therefore be able to fertilize 20565 eggs.

In conclusion, the information provided here is pertinent to fisheries ecologists and also has implications for selective breeding programs and aquaculture production of marine flatfishes. Additionally, we show that studying gamete biology can provide an opportunity to learn much about a species reproductive ecology in a very short period of time.

Acknowledgements. The authors are grateful to our industrial partner G. Guptill (Bayshore Lobster). Thanks to M. Horne for assistance with experimentation. Funding for this study was provided by the Natural Sciences and Engineering Research Council of Canada (M.K.L.: Discovery, Strategic and CRD grants; I.A.E.B.: PGS D3), AquaNet (AP20: Litvak, Lall, Hammell and Trippel), New Brunswick Innovation Fund (NBIF) and a Ministry of Research and Innovation postdoctoral fellowship grant (I.A.E.B.). All winter flounder were handled according to CCAC guidelines.

\section{LITERATURE CITED}

Alavi SMH, Butts IAE, Hatef A, Babiak I, Mommens M, Trippel EA, Litvak MK (2011) Sperm morphology, seminal plasma composition, ATP content and analysis of sperm motility and flagellar wave parameters in Atlantic halibut (Hippoglossus hippoglossus L.). Can J Zool 89: 219-228

Almeida FFL, Kristoffersen C, Taranger GL, Schulz RW (2008) Spermatogenesis in Atlantic Cod (Gadus morhua): a novel model of cystic germ cell development. Biol Reprod 78:27-34

> Asturiano JF, Pérez L, Garzón DL, Marco-Jiménez F, Peñaranda DS, Vicente JS, Jover M (2005) Physiochemical characteristics of seminal plasma and development of media and methods for the cryopreservation of European eel sperm. Fish Physiol Biochem 30:283-293

Bigelow HB, Schroeder WC (1953) Fishes of the Gulf of Maine. US Fish Wildl Serv Fish Bull 53:276-283

Billard R (1975) L'insémination artificielle de la truite Salmo gairdneri Richardson. V. - Effets de la dilution et définition du rapport optimum gamètes/dilueur. Bull Fr Piscic 257:121-135 
Buckley LJ, Smigielski AS, Halavik TA, Caldarone EM, Burns BR, Laurence GC (1991) Winter flounder Pseudopleuronectes americanus reproductive success. II. Effects of spawning time and female size on size, composition and viability of eggs and larvae. Mar Ecol Prog Ser 74: 125-135

Burness G, Moyes CD, Montgomerie R (2005) Motility, ATP levels and metabolic enzyme activity of sperm from the bluegill (Lepomis macrochirus). Comp Biochem Physiol A 140:11-17

Butts IAE, Litvak MK (2007a) Parental and stock effects on embryo and early larval development of winter flounder (Pseudopleuronectes americanus). J Fish Biol 70: 1070-1087

> Butts IAE, Litvak MK (2007b) Parental and stock effects on larval morphological development and survival to metamorphosis in winter flounder (Pseudopleuronectes americanus). Aquaculture 269:339-348

Butts IAE, Trippel EA, Litvak MK (2009) The effect of sperm to egg ratio and gamete contact time on fertilization success in Atlantic cod Gadus morhua. Aquaculture 286: 89-94

> Butts IAE, Rideout RM, Burt K, Samuelson S and others (2010) Quantitative semen parameters of Atlantic cod (Gadus morhua) and their physiological relationships with sperm activity and morphology. J Appl Ichthyology 26:756-762

> Butts IAE, Trippel EA, Ciereszko A, Soler C and others (2011) Seminal plasma biochemistry and spermatozoa characteristics of Atlantic cod (Gadus morhua L.) of wild and cultivated origin. Comp Biochem Physiol A 159: 16-24

> Casselman SJ, Schulte-Hostedde AI, Montgomerie R (2006) Sperm quality influences male fertilization success in walleye (Sander vitreus). Can J Fish Aquat Sci 63: 2119-2125

Chereguini O, García de la Banda I, Rasines I, Fernandez A (1999) Artificial fertilization in turbot, Scophthalmus maximus (L.): different methods and determination of the optimal sperm-egg ratio. Aquacult Res 30:319-324

Ciereszko A, Glogowski J, Dabrowski K (2000) Fertilization in landlocked sea lamprey: storage of gametes, optimal sperm:egg ratio, and methods of assessing fertilization success. J Fish Biol 56:495-505

Erdahl AW, Graham EF (1987) Fertility of teleost semen as affected by dilution and storage in a seminal plasma mimicking medium. Aquaculture 60:311-321

Faria A, Morais P, Chícharo MA (2006) Ichthyoplankton dynamics in the Guadiana estuary and adjacent coastal area, South-East Portugal. Estuar Coast Shelf Sci 70: 85-97

> Harmin SA, Crim LW (1993) Influence of gonadotropic hormone-releasing hormone analog (GNRH-A) on plasma sex steroid profiles and milt production in male winter flounder Pseudopleuronectes americanus (Walbaum). Fish Physiol Biochem 10:399-407

Kjørsvik E, Lønning S (1983) Effects of egg quality on normal fertilization and early development of the cod, Gadus morhua L. J Fish Biol 23:1-12

> Lahnsteiner F, Berger B, Weismann T, Patzner RA (1998) Determination of semen quality of the rainbow trout, Oncorhynchus mykiss, by sperm motility, seminal plasma parameters, and spermatozoal metabolism. Aquaculture 163:163-181

Linhart O, Rodina M, Gela D, Kocour M, Rodriguez M (2003)
Improvement of common carp artificial reproduction using enzyme for elimination of egg stickiness. Aquat Living Resour 16:450-456

Linhart O, Gela D, Rodina M, Kocour M (2004) Optimization of artificial propagation in European catfish, Silurus glanis L. Aquaculture 235:619-632

Littell RC, Milliken GA, Stroup WW, Wolfinger RD (1996) SAS system for mixed models. SAS Institute Inc., Cary, NC

- Litvak MK (1999) The development of winter flounder (Pleuronectes americanus) for aquaculture in Atlantic Canada: current status and future prospects. Aquaculture 176:55-64

- Marshall CT, Kjesbu OS, Yaragina NA, Solemdal P, Ulltang $\varnothing$ (1998) Is spawner biomass a sensitive measure of the reproductive and recruitment potential of Northeast Arctic cod? Can J Fish Aquat Sci 55:1766-1783

> Marteinsdottir G, Begg GA (2002) Essential relationships incorporating the influence of age, size and condition on variables required for estimation of reproductive potential in Atlantic cod Gadus morhua. Mar Ecol Prog Ser 235:235-256

McClelland G, Melendy J, Osborne J, Reid D, Douglas S (2005) Use of parasite and genetic markers in delineating populations of winter flounder from the central and south-west Scotian Shelf and north-east Gulf of Maine. J Fish Biol 66:1082-1100

Moksness E, Pavlov DA (1996) Management by life cycle of wolffish, Anarhichas lupus L., a new species for coldwater aquaculture: a technical paper. Aquacult Res 27: 865-883

Moulton SM, Burton MPM (1999) Histological observations on spermatogenesis in winter flounder, Pleuronectes americanus Walbaum, from Conception Bay, Newfoundland, Canada. Can J Zool 77:1682-1689

> Perchec G, Jeulin C, Cosson J, André F, Billard R (1995) Relationship between sperm ATP content and motility of carp spermatozoa. J Cell Sci 108:747-753

Rideout RM, Burton MPM (2000) The reproductive cycle of male Atlantic cod (Gadus morhua L.) from Placentia Bay, Newfoundland. Can J Zool 78:1017-1025

Rideout RM, Litvak MK, Trippel EA (2003) The development of a sperm cryopreservation protocol for winter flounder, Pseudopleuronectes americanus (Walbaum): evaluation of cryoprotectants and diluents. Aquacult Res 34:653-659

Rinchard J, Dabrowski K, Van Tassell JJ, Stein RA (2005) Optimization of fertilization success in Sander vitreus is influenced by the sperm: egg ratio and ova storage. J Fish Biol 67:1157-1161

Robbins KR, Saxton AM, Southern LL (2006) Estimation of nutrient requirements using broken-line regression analysis. J Anim Sci 84:E155-E165

Rosenthal H, Klumpp D, Willführ J (1988) Influence of sperm density and contact time on herring egg fertilization. J Appl Ichthyology 4:79-86

Rurangwa E, Roelants I, Huyskens G, Ebrahimi M, Kime DE, Ollevier F (1998) The minimum effective spermatozoa: egg ratio for artificial insemination and the effects of mercury on sperm motility and fertilization ability in Clarias gariepinus. J Fish Biol 53:402-413

Sanches EA, Baggio DM, Piana PA, de Souza BE, Bombardelli RA (2011) Artificial fertilization of oocytes and sperm activation in pacu: effects of the spermatozoa: oocyte ratio, water volume, and in natura semen preservation. R Bras Zootec 40:1-6 
SAS Institute (2003) SAS System v.9.1. SAS Institute Inc., Cary, NC

Satterthwaite FE (1946) An approximate distribution of estimates of variance components. Biom Bull 2:110-114

Scott WB, Scott MG (1988) Atlantic fishes of Canada. Can Bull Fish Aquat Sci 219:266-269

Stoner AW, Bejda AJ, Manderson JP, Phelan BA, Stehlik LL, Pessutti JP (1999) Behavior of winter flounder, Pseudopleuronectes americanus, during the reproductive season: laboratory and field observations on spawning, feeding, and locomotion. Fish Bull 97:999-1016

Suquet M, Billard R, Cosson J, Dorange G, Chauvaud L, Mugnier C, Fauvel C (1994) Sperm features in turbot (Scophthalmus maximus): a comparison with other freshwater and marine fish species. Aquat Living Resour 7: 283-294

Suquet M, Billard R, Cosson J, Normant Y, Fauvel C (1995) Artificial insemination in turbot (Scophthalmus maximus): determination of the optimal sperm to egg ratio and time of gamete contact. Aquaculture 133:83-90

Editorial responsibility: Christine Paetzold, Oldendorf/Luhe, Germany
Suquet M, Dreanno C, Dorange G, Normant Y, Quemener L, Gaignon JL, Billard R (1998) The ageing phenomenon of turbot spermatozoa: effects on morphology, motility and concentration, intracellular ATP content, fertilization, and storage capacities. J Fish Biol 52:31-41

Tambasen-Cheong Ma VP, Tan-Fermin JD, Garcia LMB, Baldevarona RB (1995) Milt-egg ratio in artificial fertilization of the Asian freshwater catfish, Clarias macrocephalus, injected salmon gonadotropin-releasing hormone analogue and domperidone. Aquat Living Resour 8:303-307

> Trippel EA (1999) Estimation of stock reproductive potential: history and challenges for Canadian Atlantic gadoid stock assessments. J Northwest Atl Fish Sci 25:61-81

> Trippel EA (2003) Estimation of male reproductive success of marine fishes. J Northwest Atl Fish Sci 33:81-113

> Trippel EA, Morgan MJ (1994) Sperm longevity in Atlantic cod (Gadus morhua). Copeia 1994:1025-1029

Zar JH (1996) Biostatistical analysis, 3rd edn. Prentice-Hall, Upper Saddle River, NJ

Submitted: January 24, 2012; Accepted: April 17, 2012

Proofs received from author(s): July 5, 2012 